\title{
ANALYSIS OF TRENDS OF LOW FLOW IN RIVER STATIONS IN EASTERN SLOVAKIA
}

\author{
M. Zeleňáková, P. Purcz, T. Soláková, B. Demeterová \\ Received: April 19, 2012
}

\begin{abstract}
ZELEŇÁKOVÁ, M., PURCZ, P., SOLÁKOVÁ, T., DEMETEROVÁ, B.: Analysis of trends of low flow in river stations in eastern Slovakia. Acta univ. agric. et silvic. Mendel. Brun., 2012, LX, No. 5, pp. 265-274

The availability of using hypothesis test techniques to identify the long-term trends of hydrological time series is investigated in this study. The aim is to analyse trends of low flows at streams in eastern Slovakia, namely Poprad, Hornád, Bodva, Bodrog river basins. The article presents a methodology for prediction of hydrological drought based on statistical testing of low stream flows by non-parametric statistical test. The main objective is to identify low flow trends in the selected 63 river stations in eastern Slovakia. The stations with human impacts are also evaluated. The Mann-Kendall nonparametric test has been used to detect trends in hydrological time series. Statistically significant trends have been determined from the trend lines for the whole territory of eastern Slovakia. The results indicate that the observed changes in Slovakian river basins do not have a clearly defined trend.
\end{abstract}

low flow, river station, trend analysis, Mann-Kendall test

In principle, the concept of drought is a deficiency of water in the atmosphere, soil and plants. Depending on where it shows a lack of water by the World Meteorological Organization - WMO (2004) classifies four basic types of drought, including: meteorological, hydrological, agricultural and socioeconomic droughts. (Mishra, Singh, 2010). The drought has a devastating impact on fauna and flora, human society and all sectors of national economy, for this it is recognized as an environmental disaster. Its effects have been observed on all continents and over the past decade the frequency of drought increases. Hydrological drought is a phenomenon which rise with existence of occurrence of noprecipitation period coupled with extreme temperatures. The genesis of hydrological drought also affects the morphological conditions of origin, climatic factors, geological and hydrogeological conditions and anthropogenic activities (Pelikán, Šlezingr, 2011). This type of drought is defined by long-term decrease in levels of surface water bodies (e.g. rivers, lakes, reservoirs) and drops in groundwater levels (Demeterová, 2008).

During the past decades, many parametric and nonparametric techniques for the detection of long-term trends in time series were developed and applied (Hirsch et al., 1991). The non-parametric
Mann-Kendall statistical test has been effectively and the most used to assess the significance of trend in hydrological time series.

A number of recent studies have identified trends in streamflows. Despite several reports on recent droughts in Europe, the non-parametric Mann-Kendall test and a resampling test for trend detection in the paper (Hisdal et al., 2001) was showed that it is not possible to conclude that drought conditions in general have become more severe or frequent. The period analysed and the selection of stations strongly influenced the regional pattern. It was also proved in the study (Stahl et al., 2010) that investigates streamflow trends in a newlyassembled, consolidated dataset of near-natural streamflow records from 441 small catchments in 15 countries across Europe. It elucidated spatial patterns and regional variability of streamflows trends. Trends were calculated by the slopes of the Kendall-Theil robust line for standardized annual and monthly streamflow, as well as for summer low flow and low flow timing.

Burn and Elnur (2002) utilizes the Mann-Kendall non-parametric test to detect trends in hydrologic variables for Canadian catchments. There were found differences in the geographic location of significant trends. 
Kapor (2000) analyzed the time series of hydrological data from 30 hydrological stations, which have a series of at least 50 years in water bodies belonging to the Danube river basin in the Republic of Serbia. The results indicate that the observed changes do not have a clearly defined trend:

The aim of this contribution is to demonstrate statistical analysis of low flows in rivers for the purpose of evaluating the long-term trend in the strength of stream flows in some catchment areas in the eastern part of Slovakia.

\section{MATERIALS AND METHODS}

\section{Study area}

Study area, as was mentioned, is situated in the eastern part of Slovakia (Fig. 1). In this territory 63 river stations are located (Tabs. I-IV). Evaluated stations are divided at stations affected by human activity and without human influence. The affected river stations (marked in the tables in grey) are considered as a station where the hydrological regime altered the flow by interference of human activities (by water works, by excessive water abstraction, etc.).

Data series of at least 36 years have been evaluated.

\section{Basic statistical characteristics of the data files}

There are many statistical methods for data evaluation. The most of useful is the nonparametric Mann-Kendall test. This analysis was carried out for statistical data from 63 evaluated river stations. These data were obtained from the Slovak Hydrometeorological Institute, regional centre Košice, during the period marked in Tabs. IIV. Because the low flow data are not comparable for the individual stations, normally it is only possible to do the statistical analysis for each river station separately. In case it becomes necessary to evaluate the data from a group of stations, the problem of aggregation of data files must be dealt with, which is the aim of this paper.

First, it was necessary to find some basic characteristics of the entry statistical data files, above all mean, median, extreme values, kurtosis and skewness.

The mean is the average value of the data files. It is most useful value in statistical analysis generally.

The median is the middle value of the ordered statistical data file, e.g. it is the value which divides the (already ordered) data file into two parts exactly. The median is not affected by loading of the extreme values (in contrast to the mean) and is a more useful characteristic than the mean in statistical analysis of low flows.

The existence of extreme values in the data file may be determined e.g. using the Box plot method. Another method known as the cutting mean leads to reduction of the original file, but without exact rules (Štipkala, 2009). The Box plot method is based on creating a so-called Box graph. This graph is the best possibility for geometrical visualisation of the distribution of random variables in some groups. These groups are created after ordering the data in the file between the extreme values, minimum and maximum. There are four groups created in this method. Each group has an identical number of data, and in mathematical statistic this is called a quartile. Tab. I shows a file divided using quartiles schematically.

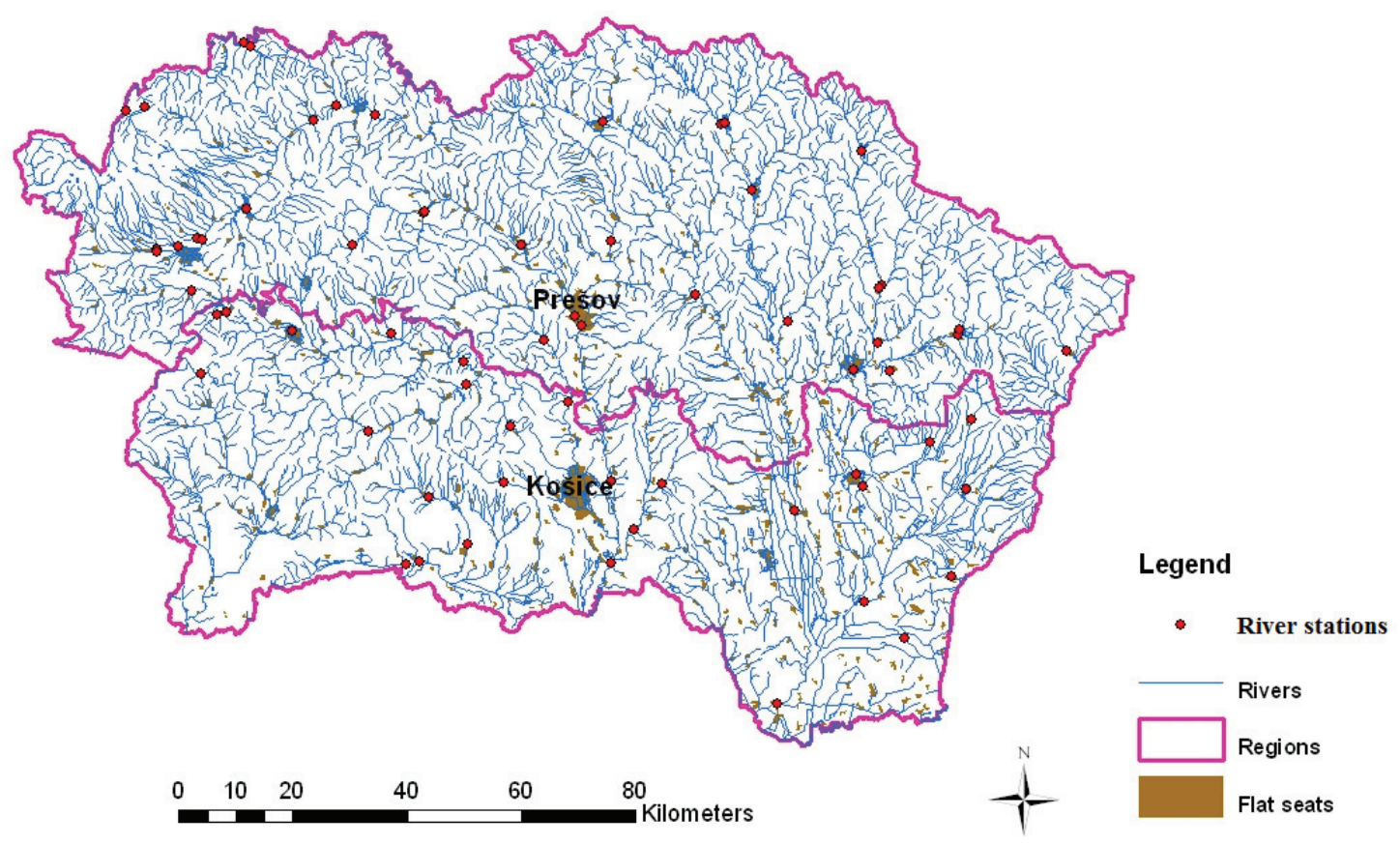

1: Aspatial distribution of river stations 
I: A quartile type of divided file

\begin{tabular}{|c|c|c|c|}
\hline \multirow{2}{*}{$\begin{array}{c}\text { Minimum is the smallest value. } \\
\text { Lower quartile Q1 }\end{array}$} & \multicolumn{2}{|c|}{ Median Q2 divides values into two equal parts } & \multirow{2}{*}{$\begin{array}{c}\text { Maximum is the biggest value. } \\
\text { Upper quartile Q3 }\end{array}$} \\
\hline & Median of the lower part & Median of the upper part & \\
\hline \multirow[b]{2}{*}{$25 \%$ of the data } & $25 \%$ of the data & $25 \%$ of the data & \multirow[b]{2}{*}{$25 \%$ of the data } \\
\hline & $\begin{array}{r}\text { Interquartile range IQR, d } \\
\text { between }\end{array}$ & $\begin{array}{l}\text { termined as the difference } \\
21 \text { and Q3 }\end{array}$ & \\
\hline
\end{tabular}
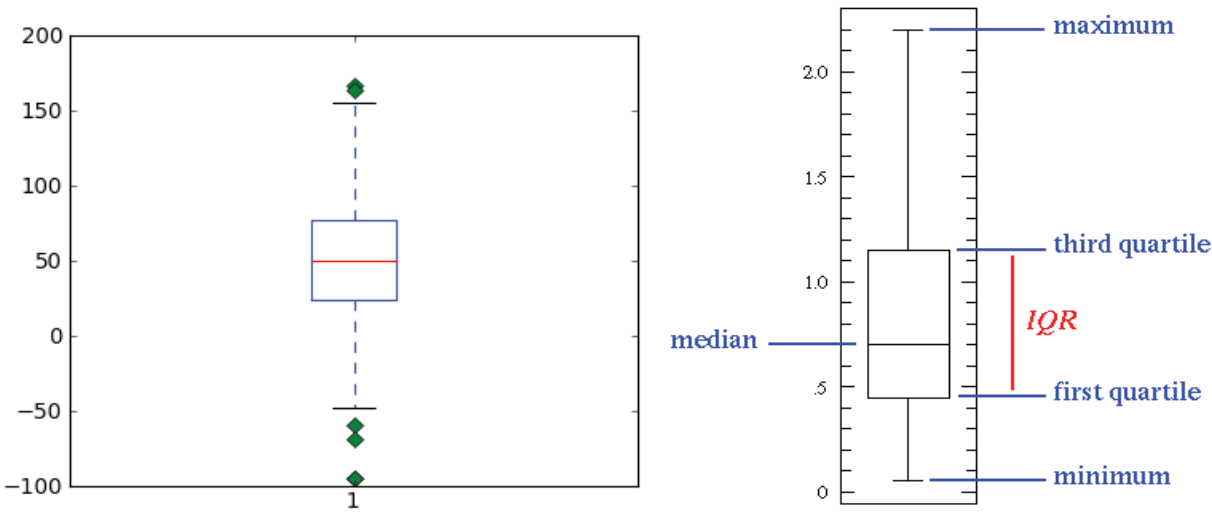

2: An example of a Box graph

The Box graph describes the occurrence of extreme data (so-called "outlet" data). They are presented as rectangles in Fig. 2. Next, in Fig. 2 it is possible to see other important values, such as the median, quartiles (lower and upper) and the interquartile range (IQR). The maximum is represented by the $75^{\text {th }}$ percentile $+1.5 \times \mathrm{IQR}$, and the minimum by the $75^{\text {th }}$ percentile $-1.5 \times$ IQR. All data lying outside this interval are extreme (outlet).

The skewness describes the form of distribution of the random variables, and measures both the direction and the degree of asymmetry of the distribution of the random variables. Positive values (as measured in our case) cause the mean to be greater than the median. It follows from this fact that the majority of the values (in all studied data files) are lower than the mean.

The kurtosis measures the "peakedness" of the distribution of the random variables, which shows the potential occurrence of extreme (outlet) data. Mostly this coefficient is compared to the coefficient of kurtosis in the Normal distribution, which equals 3.

Using this statistical analysis it was demonstrated that all entry data files contain more extreme (outlet) values. The graphs all of data files show Log-normal distribution of low flow values with large positive coefficients for both skewness and kurtosis.

\section{Mann-Kendall test}

A statistical hypothesis is an assumption about the distribution of a random variable generally. A statistical test of the hypothesis is a procedure which is used to find out whether we may "not reject" ("accept") the hypothesis, that is, act as though it is true, or whether we should "reject" it, that is, act as though it is false.

The Mann-Kendall test is a non-parametric statistical test. That means that we needn't make any assumptions about distribution of the random variable. This statistical test has a variety of applications for trend analysis (Kendall, 1975; Santos et al., 2007). Its results are relevant as long as $10 \leq n$ ( $n$ - range of the file). Only in this case can the Mann-Kendall statistic have a Normal distribution (Önöz, Bayazit, 2003). The data must be ordered chronologically in terms of one or more criteria. This test is based on the calculation of a special statistical value $S$. Comparing each of the couples $y_{\mathrm{i}}, y_{\mathrm{i}},(i>j)$ of the random value $Y$, it is possible to determine if $y_{\mathrm{i}}>y_{\mathrm{j}}$ or $y_{\mathrm{i}}<y_{\mathrm{j}}$. Let's define the number of the first type as $P$ and of the second type as $M$. Now $S$ can be defined as (Önöz, Bayazit, 2003):

$S=P-M$.

The next Mann-Kendall statistic Z has a Normal distribution, where (Kendall, 1975):

$\begin{array}{lll}Z=(S-1) / \sigma_{\mathrm{s}}^{1 / 2} & \text { if } & S>0 \\ Z=0 & \text { if } & S=0 \\ Z=(S+1) / \sigma_{\mathrm{s}}^{1 / 2} & \text { if } & S<0 .\end{array}$

The deviation $\sigma_{\mathrm{s}}$ is defined as:

$\sigma_{\mathrm{s}}=n(n-1) \times(2 n+5) / 18$,

where

$n$.... is the number of samples.

The hypothesis H0: no trend "not reject", if $Z<Z_{\alpha / 2}$ or "reject" if $Z>Z_{\alpha / 2}$. The value $\alpha$ is called the significance level; we choose $\alpha=0.05$. The 
calculation of probability of normalized $Z$ test statistics is done using the application of the standard normal distribution, which is basically given by the following expression:

$$
f(z)=\frac{1}{\sqrt{2 \pi}} e^{-\frac{z^{2}}{2}} .
$$

Moreover, the value of $Z$ gives further information about any increasing or decreasing of the trend, but not its magnitude exactly (Önöz, Bayazit, 2003; Santos et al., 2007).

All calculations, both of the basic characteristics of the entry data and of the testing of the samples were done using VisualBasic on the Microsoft Excel platform.

\section{RESULTS AND DISCUSSION}

Basic statistical characteristics of the data files are presented in following Tabs. II-V.

In analyzing the results, it is considered that there is a decreasing trend when normalized test statistics $\mathrm{Z}$ is negative, and the obtained probability is greater than the adopted level of significance. Conversely, when the normalized test statistics $Z$ is positive and obtained probability is greater than the adopted level of significance, it is considered that there is a increasing trend. If the obtained probability is less than the adopted level of significance, it is accepted that there is no trend (Kapor et al., 2011).

II: Basic statistical characteristics in river stations in Poprad basin

\begin{tabular}{lcccccccc}
\hline \multirow{2}{*}{ No. } & \multirow{2}{*}{ River Station } & \multicolumn{3}{c}{ Period } & Kurtosis & Skewness & Median & $\begin{array}{c}\text { Number of } \\
\text { extreme values }\end{array}$ \\
\cline { 3 - 5 } & from & to & total & & & & & \\
\hline 1 & Ždiar - Lysá Pol'ana & 1972 & 2010 & 39 & 1.554026 & 2.579875 & 1.235 & 16 \\
\hline 2 & Ždiar - Podspády & 1961 & 2010 & 50 & 1.385817 & 2.07331 & 0.76 & 16 \\
3 & Červený Kláštor - Kúpele & 1968 & 2010 & 43 & 1.89943 & 6.041278 & 0.41 & 17 \\
\hline 4 & Červený Kláštor & 1968 & 2010 & 43 & 0.931166 & 0.816089 & 13.8 & 4 \\
\hline 5 & Svit & 1966 & 2010 & 45 & 1.35799 & 1.653051 & 0.579 & 26 \\
\hline 6 & Svit & 1963 & 2010 & 49 & 1.769929 & 3.811689 & 0.237 & 41 \\
\hline 7 & Poprad-Velká & 1963 & 2010 & 49 & 1.507696 & 4.297559 & 0.46 & 19 \\
\hline 8 & Poprad-Matejovce & 1962 & 2010 & 49 & 1.131653 & 1.919848 & 0.279 & 16 \\
\hline 9 & Kežmarok & 1972 & 2010 & 39 & 2.000563 & 5.511457 & 0.36 & 25 \\
\hline 10 & Nižné Ružbachy & 1974 & 2010 & 37 & 1.248576 & 1.67138 & 5.899 & 17 \\
\hline 11 & Hniezdne & 1972 & 2010 & 39 & 1.436049 & 2.549134 & 0.124 & 17 \\
\hline 12 & Chmelnica & 1931 & 2010 & 80 & 1.598901 & 3.609744 & 7.11 & 34 \\
\hline
\end{tabular}

III: Basic statistical characteristics in river stations in Hornád basin

\begin{tabular}{|c|c|c|c|c|c|c|c|c|}
\hline \multirow{2}{*}{ No. } & \multirow{2}{*}{ Station } & \multicolumn{3}{|c|}{ Period } & \multirow{2}{*}{ Kurtosis } & \multirow{2}{*}{ Skewness } & \multirow{2}{*}{ Median } & \multirow{2}{*}{$\begin{array}{c}\text { Number of } \\
\text { extreme values }\end{array}$} \\
\hline & & from & to & total & & & & \\
\hline 13 & Hranovnica & 1965 & 2010 & 45 & 2.044337 & 6.020411 & 0.3315 & 27 \\
\hline 14 & Hrabušice & 1967 & 2010 & 44 & 2.88779 & 15.51134 & 0.774 & 19 \\
\hline 15 & Hrabušice - Podlesok & 1972 & 2010 & 39 & 1.204042 & 2.990362 & 0.248 & 11 \\
\hline 16 & Spišská Nová Ves & 1972 & 2010 & 39 & 2.068367 & 7.152126 & 1.317 & 14 \\
\hline 17 & Spišské Vlachy & 1975 & 2010 & 36 & 1.954649 & 6.447947 & 0.28 & 18 \\
\hline 18 & Margecany & 1972 & 2010 & 39 & 2.361353 & 9.367487 & 3.5995 & 26 \\
\hline 19 & Stratená & 1954 & 2010 & 57 & 1.929821 & 4.994504 & 0.479 & 35 \\
\hline 20 & Švedlár na Hrabliach & 1931 & 2010 & 80 & 1.842699 & 3.956677 & 1.5535 & 66 \\
\hline 21 & Jaklovce & 1931 & 2010 & 80 & 2.080526 & 5.453678 & 2.589 & 72 \\
\hline 22 & Košická Belá & 1974 & 2010 & 37 & 2.060845 & 5.618473 & 0.087 & 23 \\
\hline 23 & Kysak & 1929 & 2010 & 82 & 2.344298 & 7.271084 & 7.3 & 85 \\
\hline 24 & Nižné Repaše & 1975 & 2010 & 36 & 2.351989 & 8.744696 & 0.0935 & 31 \\
\hline 25 & Brezovica & 1973 & 2010 & 38 & 1.990774 & 5.837077 & 0.1475 & 20 \\
\hline 26 & Sabinov & 1973 & 2010 & 38 & 1.742292 & 3.969851 & 1.18 & 20 \\
\hline 27 & Prešov & 1970 & 2010 & 41 & 1.724631 & 4.083802 & 1.65 & 22 \\
\hline 28 & Demjata & 1973 & 2010 & 38 & 1.238889 & 1.343055 & 0.3055 & 29 \\
\hline 29 & Prešov & 1961 & 2010 & 50 & 2.052677 & 6.349703 & 0.6445 & 32 \\
\hline
\end{tabular}




\begin{tabular}{lcccccccc}
\hline \multirow{2}{*}{ No. } & Station & \multicolumn{3}{c}{ Period } & Kurtosis & Skewness & Median & $\begin{array}{c}\text { Number of } \\
\text { extreme values }\end{array}$ \\
\cline { 3 - 7 } & from & to & total & & & & \\
& Košické Olšany & 1931 & 2010 & 80 & 1.984643 & 6.990796 & 3.02 & 29 \\
31 & Svinica & 1973 & 2010 & 38 & 2.124086 & 5.476892 & 0.06 & 40 \\
32 & Bohdanovce & 1966 & 2010 & 45 & 2.383099 & 8.955003 & 0.3265 & 30 \\
33 & Ždaňa & 1958 & 2010 & 53 & 2.364586 & 7.426313 & 11.915 & 54 \\
\hline
\end{tabular}

IV: Basic statistical characteristics in river stations in Bodva basin

\begin{tabular}{ccccccccc}
\hline \multirow{2}{*}{ No. } & Station & \multicolumn{3}{c}{ Period } & Kurtosis & Skewness & Median & $\begin{array}{c}\text { Number of } \\
\text { extreme values }\end{array}$ \\
\cline { 3 - 7 } & & from & to & total & & & & \\
\hline 34 & Nižný Medzev & 1941 & 2010 & 70 & 2.162925 & 6.137853 & 0.251 & 64 \\
\hline 35 & Moldava nad Bodvou & 1965 & 2010 & 46 & 2.146241 & 5.762377 & 0.341 & 41 \\
\hline 36 & Hýlov & 1965 & 2010 & 46 & 3.727486 & 23.54098 & 0.1475 & 28 \\
\hline 37 & Turňa nad Bodvou & 1966 & 2010 & 45 & 2.328922 & 7.631559 & 0.9375 & 45 \\
\hline 38 & Hostovce & 1968 & 2010 & 43 & 2.628787 & 9.080273 & 0.2025 & 43 \\
\hline
\end{tabular}

V: Basic statistical characteristics in river stations in Bodrog basin

\begin{tabular}{|c|c|c|c|c|c|c|c|c|}
\hline \multirow{2}{*}{ No. } & \multirow{2}{*}{ Station } & \multicolumn{3}{|c|}{ Period } & \multirow{2}{*}{ Kurtosis } & \multirow{2}{*}{ Skewness } & \multirow{2}{*}{ Median } & \multirow{2}{*}{$\begin{array}{c}\text { Number of } \\
\text { extreme values }\end{array}$} \\
\hline & & from & to & total & & & & \\
\hline 39 & Medzilaborce & 1975 & 2010 & 36 & 1.969083 & 5.43406 & 0.223 & 23 \\
\hline 40 & Jabloň & 1975 & 2010 & 36 & 1.590893 & 3.095441 & 0.2705 & 18 \\
\hline 41 & Kokošovce & 1961 & 2010 & 50 & 7.232974 & 101.9174 & 1.062 & 33 \\
\hline 42 & Udavské & 1975 & 2010 & 36 & 1.663648 & 4.150873 & 0.52 & 14 \\
\hline 43 & Snina & 1957 & 2010 & 54 & 1.695406 & 3.443234 & 0.797 & 40 \\
\hline 44 & Snina & 1975 & 2010 & 36 & 1.46199 & 2.463163 & 0.126 & 13 \\
\hline 45 & Kamenica nad Cirochou & 1961 & 2010 & 50 & 2.923875 & 12.89779 & 0.26 & 43 \\
\hline 46 & Humenné & 1967 & 2010 & 44 & 2.480386 & 13.64994 & 3.5825 & 20 \\
\hline 47 & Michalovce - Stráňany & 1962 & 2010 & 49 & 1.927579 & 4.563265 & 2.4865 & 40 \\
\hline 48 & Jovsa & 1970 & 2010 & 41 & 2.104789 & 6.216189 & 0.086 & 31 \\
\hline 49 & Michalovce-Medov & 1955 & 2010 & 56 & 1.172373 & 1.319246 & 5.25 & 16 \\
\hline 50 & Ulič & 1972 & 2010 & 39 & 2.774549 & 11.53484 & 0.307 & 18 \\
\hline 51 & Lekárovce & 1951 & 2010 & 60 & 1.905658 & 5.0883 & 7.543 & 30 \\
\hline 52 & Remetské Hámre & 1955 & 2010 & 56 & 2.546627 & 9.075364 & 0.294 & 45 \\
\hline 53 & Sobrance & 1970 & 2010 & 41 & 1.702476 & 3.742496 & 0.22 & 28 \\
\hline 54 & Ižkovce & 1975 & 2010 & 36 & 2.220385 & 6.096453 & 20.545 & 34 \\
\hline 55 & Velké Kapušany & 1951 & 2010 & 60 & 2.086689 & 5.389429 & 11.59 & 55 \\
\hline 56 & Bardejov & 1967 & 2010 & 44 & 1.681923 & 3.603626 & 1.1205 & 23 \\
\hline 57 & Hanušovce nad Topl'ou & 1931 & 2010 & 80 & 2.116909 & 7.988851 & 2.9 & 38 \\
\hline 58 & Svidník & 1962 & 2010 & 49 & 9.318237 & 149.7023 & 0.34 & 23 \\
\hline 59 & Svidník & 1962 & 2010 & 49 & 2.138821 & 7.177429 & 0.405 & 21 \\
\hline 60 & Stropkov & 1967 & 2010 & 44 & 4.074425 & 36.50911 & 1.245 & 22 \\
\hline 61 & Jasenovce & 1957 & 2010 & 54 & 1.589772 & 2.876338 & 0.3 & 25 \\
\hline 62 & Horovce & 1931 & 2010 & 80 & 3.032593 & 19.04556 & 7.79 & 37 \\
\hline 63 & Streda nad Bodrogom & 1951 & 2010 & 60 & 2.599394 & 9.194828 & 43.285 & 56 \\
\hline
\end{tabular}

The results of calculations of a possible existence of the trend using the Mann-Kendall test at river stations on the territory of eastern Slovakia in river basins Poprad, Hornád, Bodva, Bodrog are presented in Tabs. VI-IX (stations affected by human activities are marked in grey).
The results of analysis of a possible trend shown in Tabs. VI-IX indicate that it is not possible to determine with reasonable certainty, the existence of trend in time series of low flows at evaluated river stations. 
There have been detecting trend in sixteen river stations which is $25 \%$ of all river stations. In ten river stations have appeared a decreasing trend (marked in Tables in Bold) of low flows mainly in the smallest river basin - Bodva. In six cases from the entire river stations have been found an increasing trend of low stream flows.

It is interesting that at seven river stations (50\%) from a total of fourteen river stations located in parts of watercourses where there is an influence of man and its activities a significant trend was noted. It is where hydraulics structures are situated. At four river stations (Švedlár na Hrabliach, Jaklovce, Brezovica and Hostovce) from mentioned seven stations influenced by human activities this significant trend is decreasing. River stations Švedlár na Hrabliach and Jaklovce are located upstream of large Ružín dam. At the remaining seven stations there is no trend, based on the results of the test.

On the basis of the methodology applied the existence of trend in most of the evaluated river stations was not recorded. Only a small number of cases depict the decreasing trend in the time series of low flows. It was proven slightly statistically

VI: Results of the trend analysis in Poprad basin

\begin{tabular}{ccccc}
\hline No. & Mann Kendall $(S)$ & Normalized $(Z)$ & Probability & $\begin{array}{c}\text { Trend } \\
\text { 95\% significance }\end{array}$ \\
\hline 1 & -71 & 0.846781 & 0.860592 & no \\
\hline 2 & 62 & 0.52581 & 0.826238 & no \\
3 & 106 & 1.098869 & 0.890911 & no \\
4 & 127 & 1.318643 & 0.916361 & no \\
5 & 162 & 1.574953 & 0.942275 & no \\
6 & -196 & 1.733168 & 0.955567 & decreasing \\
7 & 253 & 2.239786 & 0.983758 & increasing \\
\hline 8 & 193 & 1.655008 & 0.949276 & no \\
\hline 9 & 93 & 1.112912 & 0.892592 & no \\
10 & 34 & 0.431603 & 0.818223 & increasing \\
11 & 188 & 2.262115 & 0.984554 & decreasing \\
\hline
\end{tabular}

VII: Results of the trend analysis in Hornád basin

\begin{tabular}{lcccc}
\hline No. & Mann Kendall $(S)$ & Normalized $(Z)$ & Probability & $\begin{array}{c}\text { Trend } \\
\text { 95\% significance }\end{array}$ \\
\hline 13 & -107 & 1.003624 & 0.879423 & no \\
14 & 20 & 0.213407 & 0.80497 & no \\
15 & -7 & 0.072581 & 0.801003 & no \\
16 & 47 & 0.556456 & 0.829096 & no \\
17 & 78 & 1.048809 & 0.884886 & no \\
18 & 107 & 1.282268 & 0.912309 & no \\
19 & -180 & 1.232209 & 0.906613 & decreasing \\
20 & -886 & 3.676876 & 0.999769 & decreasing \\
21 & -624 & 2.588355 & 0.992998 & no \\
22 & 10 & 0.11771 & 0.801856 & no \\
23 & -243 & 0.969078 & 0.875243 & decreasing \\
24 & 98 & 1.321227 & 0.916645 & no \\
25 & -141 & 1.760067 & 0.957606 & no \\
\hline 26 & -31 & 0.377157 & 0.814176 & decreasing \\
\hline 27 & -66 & 0.730076 & 0.847156 & no \\
\hline 28 & -140 & 1.747495 & 0.956661 & no \\
\hline 29 & -11 & 0.083649 & 0.801175 & no \\
\hline 30 & -36 & 0.145413 & 0.802577 & no \\
\hline 31 & 15 & 0.176007 & 0.803545 & 0.886992 \\
\hline 32 & -110 & 1.066273 & 0.80604 & \\
\hline
\end{tabular}


VIII: Results of the trend analysis in Bodva basin

\begin{tabular}{ccccc}
\hline No. & Mann Kendall $(S)$ & Normalized $(Z)$ & Probability & $\begin{array}{c}\text { Trend } \\
\text { 95\% significance }\end{array}$ \\
\hline 34 & -493 & 2.494272 & 0.991107 & decreasing \\
35 & -179 & 1.685331 & 0.951781 & decreasing \\
36 & -127 & 1.318643 & 0.916361 & no \\
37 & -90 & 0.870626 & 0.863418 & no \\
38 & -239 & 2.49077 & 0.991029 & decreasing \\
\hline
\end{tabular}

IX: Results of the trend analysis in Bodrog basin

\begin{tabular}{|c|c|c|c|c|}
\hline No. & Mann Kendall (S) & Normalized $(Z)$ & Probability & $\begin{array}{c}\text { Trend } \\
\text { 95\% significance }\end{array}$ \\
\hline 39 & -106 & 1.430194 & 0.928249 & no \\
\hline 40 & -58 & 0.776391 & 0.852396 & no \\
\hline 41 & -51 & 0.418243 & 0.817188 & no \\
\hline 42 & -64 & 0.858116 & 0.861933 & no \\
\hline 43 & 197 & 1.462239 & 0.931499 & no \\
\hline 44 & -16 & 0.204313 & 0.8046 & no \\
\hline 45 & 147 & 1.221269 & 0.905351 & no \\
\hline 46 & -32 & 0.313542 & 0.810049 & no \\
\hline 47 & 16 & 0.129298 & 0.802139 & no \\
\hline 48 & -46 & 0.505437 & 0.824403 & no \\
\hline 49 & 572 & 4.035562 & 0.999942 & increasing \\
\hline 50 & -97 & 1.1613 & 0.898342 & no \\
\hline 51 & 230 & 1.460546 & 0.931329 & no \\
\hline 52 & -284 & 2.000112 & 0.973004 & decreasing \\
\hline 53 & -126 & 1.403992 & 0.925535 & no \\
\hline 54 & -52 & 0.694666 & 0.843251 & no \\
\hline 55 & 216 & 1.371255 & 0.922074 & no \\
\hline 56 & -40 & 0.394456 & 0.815412 & no \\
\hline 57 & 64 & 0.261744 & 0.807197 & no \\
\hline 58 & 40 & 0.336174 & 0.81144 & no \\
\hline 59 & -162 & 1.574953 & 0.942275 & no \\
\hline 60 & -82 & 0.819255 & 0.857359 & no \\
\hline 61 & 466 & 3.469087 & 0.999514 & increasing \\
\hline 62 & 773 & 3.207399 & 0.998836 & increasing \\
\hline 63 & 332 & 2.111094 & 0.978511 & increasing \\
\hline
\end{tabular}

significant impact of human activities for the hydrological regime of rivers.

Statistical tests can only indicate the significance of the observed test statistics and do not provide unequivocal findings. It is therefore important to clearly understand the interpretation of the results and to corroborate findings with physical evidence of the causes, such as land use changes or river stations influenced by human activities. Changes in streamflow drought severity and frequency might occur as a result of changes in climate (mainly precipitation and temperature) and artificial influences in the catchment such as groundwater abstraction, irrigation and urbanization (Hisdal et al., 2001). Even so, low flow data are especially prone to artificial influences in a catchment, and the results presented in this paper may have been affected by this. The causes of a change in riverflow behaviour often do not have a simple explanation, and a further study would require a detailed analysis at the catchment scale, which is beyond the scope of this paper. However, the spatial consistency in the results does indicate some systematic factors that can be evaluated at a qualitative, regional level. 


\section{SUMMARY}

The paper presents the problem of drought and describes its classification and methods of assessing this risk. The goal of paper is the assessment of the extreme hydrological phenomena - drought, in the recent years, in the territory of eastern Slovakia. The task of this paper is to identify statistically significant trends in stream flow characteristics of low water content in eastern Slovakia, which are used in the evaluation of hydrological drought. Methodology for evaluating hydrological drought is based on statistical analysis of observed low stream flows at river stations. Mann-Kendall statistical test identifies the frequency of low stream flow trends. The hydrological drought is defined by longterm decrease in levels of surface water bodies (e.g. rivers, lakes, reservoirs and other) and drops in groundwater levels. Low water content is proof of this type of drought. Hydrological drought analyses in terms of stream flow deficits are said to be studies over a season or longer time periods and in a regional context.

The article presents a methodology for prediction of hydrological drought risk based on statistical testing of flow characteristics of low water content (annual stream flow) by non-parametric statistical test. The main objective is to identify low stream flow trends in the selected 63-five river stations in eastern Slovakia in the time interval till year 2010. The Mann-Kendall non-parametric test has been used to detect trends in hydrological time series. Some of stream flow records in rivers in eastern Slovakia are affected by human activities and another are without influence.

Statistical tests can detect the existence of trends in hydrological time series. The purpose of the tests is to detect a statistically significant trend of decrease or increase of the low flow values. Non-parametric Mann-Kendall test doesn't make assumption on the probability distribution of random variable. It has wide application in testing of hydro-meteorological characteristics.

The results confirmed not significant rising incidence trends of decreasing of low flows in the streams in eastern Slovakia (in ten from all sixty-three river stations was found decreasing trend). In the complex vulnerability assessment of territory owing to drought is essential to take into account also the parameters as temperature, precipitation and groundwater levels.

\section{Acknowledgement}

The Centre was supported by the Slovak Research and Development Agency under the contract No. SUSPP-0007-09.

\section{REFERENCES}

BURN, D.H. and ELNUR, M. A. H., 2002: Detection of hydrologic trends and variability. J. Hydrol., 255, p. 107-122.

DEMETEROVÁ, B. and ŠKODA, P., 2008: Low water content of selected rivers in Slovakia (in Slovak). J.Hydrol.Hydromech., 57, 1: 55. ISSN 0042-790X.

HIRSCH, R. M., ALEXANDER, R. B. and SMITH, R. A., 1991: Selection of methods for the detection and estimation of trends in water quality, Water Resour. Res., 27, p. 803-813.

HISDAL, H., STAHL, K., TALLAKSEN, L. and DEMUTH, S., 2001: Have streamflow droughts in europe become more severe or frequent? Int. J. Climatol. 21: 317-333.

KAPOR, B., MARJANOVIC, S. and CATOVIC, S., 2011: On the Analysis of Trends of Average Flow on Watercourses in Serbia which belong to the Danube River Basin [cit. 2011-06-07]. Available at: ftp://152.66.18.61/Floodrisk/_DC/docs/4_26_ prohaska.pdf.

KENDALL, M., 1975: Rank Correlation Methods, 4th ed. Charles Griffin, London.

MISHRA, K. and SINGH, P., 2010: A review of drought concepts. Journal of Hydrology. USA: Texas A\&M University, Civil and Environmental
Engineering, p. 203-212 [cit. 2010-09-11]. Available at: $\langle$ www.elsevier.com/locate/jhydrol $>$.

ÖNÖZ, B. and BAYAZIT, M., 2003: The Power of Statistical Tests for Trend Detection. Turkish J. Eng. Env. Sci. 27: 247-251, [cit. 2008-12-11]. Available at: <http://journals.tubitak.gov.tr/engineering/ issues/muh-03-27-4/muh-27-4-5-0206-6.pdf $>$.

PELIKÁN, P. and ŠLEZINGR, M., 2011:Methodology for the establishment of physical and geometric properties of a drainage basin. Acta univ. agric. et silvic. Mendel. Brunen. 59, 6: 265-270. ISSN 12118516.

SANTOS, J. and PORTELA, M., 2007: Monitoring of monthly and annual series of precipitation (in Portugal), Portugal: Department of Engineering, p. 1-11.

STAHL, K., HISDAL, H., HANNAFORD, J., TALLAKSEN, L., VAN LANEN, H., SAUQUET, E., DEMUTH, S., FENDEKOVA, M. and JORDAR, J., 2010: Streamflow trends in Europe: evidence from a dataset of near-natural catchments. Hydrol. Earth Syst. Sci., 14, p. 2367-2382.

ŠŤAVINA, P., 2010: Algorithms of scientific and technical computations (in Slovak). 20 p. [cit. 2011-01-30]. Available at: <http://stavina.dnp.fmph.uniba.sk/ algoritmy/sci-algs_textbook.pdf $>$. 


\section{Address}

doc. Ing. Martina Zeleňáková, PhD., Ing. Tatiana Soláková, Ústav environmentálneho inžinierstva, RNDr. Pavol Purcz, PhD., Ústav technológie a manažmentu v stavebníctve, Stavebná fakulta, Technická univerzita v Košiciach, Vysokoškolská 4, 04200 Košice, Slovenská republika, Mgr. Beáta Demeterová, PhD., Slovenský hydrometeorologický ústav, Regionálne stredisko Košice, Ďumbierska 26, 04117 Košice, Slovenská republika, e-mail: martina.zelenakova@tuke.sk, tanik@post.sk, pavol.purcz@tuke.sk, beata. demeterova@gmail.com 
